\title{
Muntingia calabura L. (Elaeocarpaceae): A New Generic Record to the Flora of Gujarat State, India.
}

\section{P. K. Patel ${ }^{1 *}$, Vandana Vyas ${ }^{1}$ and A. V. Pandya ${ }^{2}$}

${ }^{1}$ Department of Botany, S.P.T Arts \& Science College, Godhra, Gujarat, India.

2Department of Botany, M.P. Pandya Science College, Lunawada, Gujarat, India.

Received: January 12, 2016; Revised: January 21, 2016; Accepted: February 18, 2016.

\begin{abstract}
The present paper deals with the genus Muntingia L., belonging to family Elaeocarpaceae. It is reported here as an addition to the Flora of Gujarat State. The paper also envisages brief citation, description, phenological data and illustrations of the species. The details of nomenclatural citation followed by description, phenological data, habitat and colour photographs are provided.
\end{abstract}

Key Words: Elaeocarpaceae, Godhra, Gujarat, India, Muntingia, New record.

\section{Introduction}

Muntingia calabura L. (Jamaica cherry) is indigenous to southern Mexico, Central America, tropical South America, the Greater Antilles, St. Vincent and Trinidad. Muntingia calabura L. is widely cultivated in warm areas of the New World and in India, Southeast Asia, Malaya, Indonesia, and Philippines (Morton, 1987). It is also commonly found of the wild in southern Taiwan (Boufford et al., 2003).

During the botanical exploration of around Godhra, Panchmahals Districts, Gujarat, the author collected specimens of an interesting plant. After critical examination and going thorough literature, the identity of the specimens determined as Muntingia calabura L. (Elaeocarpaceae). So far, this taxon has not been recorded from the State (Blatter, 1908-1909; Saxton \& Sedgwick, 1918; Saxton, 1922; Thakar, 1926; Santapau, 1962; Shah, 1978; Raghavan et al., 1981; Bole \& Pathak, 1988; Pilo et al., 1996; Pandey \& Singh, 1999; Singh \& Parabia, 2003). The present finding forms a new record for Gujarat, India.

This plant has several vernacular names like straw berry tree, Jamaican cherry (English), Chinese cherry (or) Japanese cherry (India), cherry chettu (Telugu), Krakhob (Cambodian), Bois Ramier (French), Kersen (Indonesian), Takhob (Laotian), Kerukup siam (Malay), Calabura, Páo De Seda (Portuguese), Calabura or Capulin(Spanish), Takhop farang (Thai) and Trung camat sam (Vietnamese) (Fosberg et al., 1979).

\section{Taxonomic Description:}

Muntingia calabura L., Sp. Pl. 509. 1753; Manilal \& Sivar., Fl. Calicut 54. 1982; Babu, Fl. Malappuram Dist. 90. 1990; S.K. Murti in B.D. Sharma \& Sanjappa, Fl. India 3: 570. 1993; M. Reema et al. in P. Daniel, Fl. Kerala 1: 505. 2005; Sunil \& Sivadasan, Fl. Alappuzha Dist. 146. 2009; Ratheesh Narayanan, Fl. Stud. Wayanad Dist. 175. 2009. (Figure 1)

\section{Corresponding Author}

Prof. P. K. Patel,

Department of Botany,

S.P.T Arts \& Science College,

Godhra, Gujarat, INDIA.

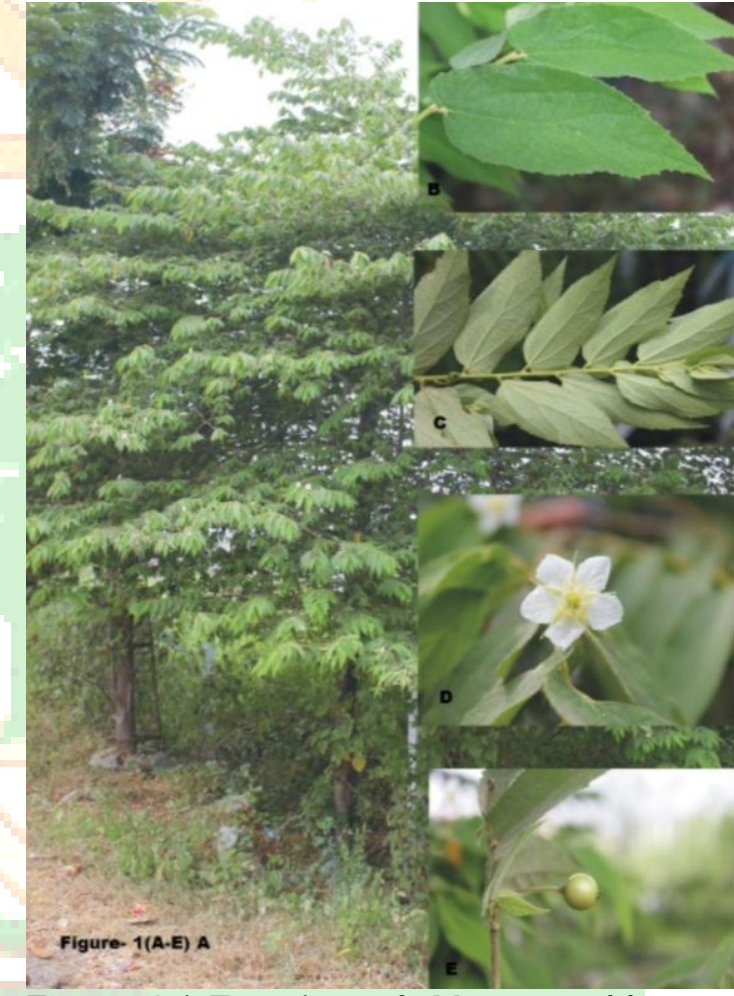

Figure 1(A-E): Plate of Muntingia calabura L.

(Elaeocarpaceae)

$$
\begin{aligned}
& \text { A: Plant; B: Leaves (Dorsal Part) } \\
& \text { C: Leaves (Ventral Part); D: Flower } \\
& \text { E: Fruit (Unripen) }
\end{aligned}
$$

Trees, to $7 \mathrm{~m}$ high with spreading, nearly horizontal branches; branchlets densely villous, glandular pubescent. Leaves evergreen, simple, alternate; stipules 1 linear, $5 \mathrm{~mm}$ long, lateral, filiform, hairy; petiole $5 \mathrm{~mm}$ long; lamina 611 × 24 $\mathrm{cm}$, lanceolate or oblonglanceolate, base obliquely subcordate, apex acuminate, margin serrate, glandular hairy above, woolly beneath; lateral nerves 35 pairs, pinnate, prominent, intercostae reticulate, prominent. Inflorescences supraaxillary, usually 1flowered. Flowers bisexual, $1.53 \mathrm{~cm}$ across, white; pedicels $22.5 \mathrm{~cm}$ long; sepals $5,1.5$ $\mathrm{cm}$ long, lanceolate, valvate, shortly connate at 
base, densely pubescent; petals 5, thin, ovate, obovate or suborbicular, shortly clawed, entire, imbricate, crumpled in bud; intrastaminal disc annular, bearing a ring of hairs on the exterior margin; stamens many, yellow, ca. $1 \mathrm{~cm}$ long; filaments filiform; ovary superior, $56 \mathrm{~mm}$ long, ellipsoid, 5celled, ovules many; styles short; stigmas capitate, 5 grooved. Fruit a berry, $11.5 \mathrm{~cm}$ across, red or yellow, subglobular; seeds many, obovoid ellipsoid, many.

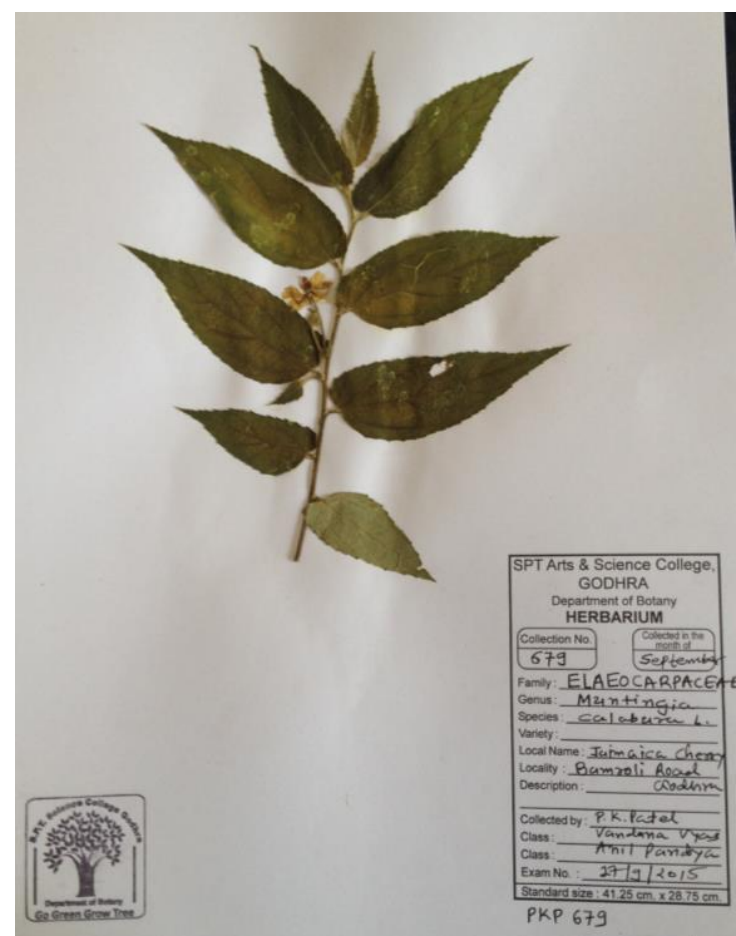

Figure 2:

Flowers \& Fruits: Throughout the year

Native: Southern Mexico, Central America.

Distribution: India; Gujarat; Maharashtra; Karnataka; Tamil Nadu.

Specimens Examined: INDIA. Gujarat, Panchmahals District, Near Vavdi Buzurg, Bamroli Road, Godhra, $22.7773^{\circ} \mathrm{N}, 73.6203^{\circ}$ alt. $73 \mathrm{~m}, 17$ September 2015, PKP 00679(Department of Botany, SPT Science College, Godhra) (Figure-2)

\section{Acknowledgement}

The authors are thankful to Dr. Rohan Pandya, Biodiversity Gene Bank, Gandhinagar, India and Prof. Ram Suthar, Science College, Kadi, Gujarat, India for valuable suggestions and encouragement. We wish also thank Dr. Sarju Prajapati and Mr. Naranbhai R. Baria for their constant support during field work.

\section{References}

1. Blatter, E, On the flora of Kutch. J. Bombay Nat. Hist. Soc. 18 (1908-09): 756-776.

2. Bole, PV and Pathak, JM, Flora of Saurashtra, Botanical Survey of India, Calcutta 1988, Vol. II III.

3. Boufford DE, Ohashi H, Huang TC, Hsieh CF, Tsai JL, Yang KC, Peng CI, Kuoh CS and Hsiao A, A Checklist of the Vascular Plants of Taiwan, Flora of Taiwan, National Taiwan University Herbarium, Taipei, Taiwan, 6(2003): 76.

4. Cooke T, The Flora of Bombay Presidency, London, 1901-08, Vol. 2.

5. Fosberg FR, Sachet MH and Oliver RL, A geographical checklist of the Micronesian dicotyledonae, Micronesica, 15(1979): 1-295.

6. Morton JF and Jamaica Cherry, in: Fruits of Warm Climates, Creative Resource Systems, Inc., Miami, L. (eds.) US, (1987): 65-69.

7. Pandey RP and Singh V, Gujarat: Floristic diversity and conservation strategies in India, In Mudgal V, Hajara PK, Flora of India, Botanical Survey of India, Kolkata, 2(1999): 775 806.

8. Pilo B, Pathak BJ, Kumar BA, Muruksan VK, Vinod KR and Kumari S, Biological diversity of Gujarat - Current knowledge, Gujarat Ecological Commission, Vadodara, 1996.

9. Raghvan RS, Wadhwa BM, Ansari MY and Rolla S Rao, A check list of plants of Gujarat. Rec. Bot. Surv. India, 21, 2 (1981): 1 -127.

10. Santapau H, The Flora of Saurashtra, Saurashtra Research Society, Rajkot, 1962, Vol. 1.

11. Saxton WT, Additional notes on plants of north Gujarat, Rec. Bot. Surv. India, 9, 3(1922): 251-226.

12. Saxton WT, Sedgwick LJ, Plants of north Gujarat, Rec. Bot.Surv. India, 6 (1918): 207-323.

13. Shah GL, Flora of Gujarat State, Sardar Patel University, Vallabh Vidhyanagar, Gujarat, 1978, Vol. I-II

14. Singh AP and Minoo Parabia, The floral diversity of Gujarat State: A review, Indian Forester, 129, 12 (2003): 1461-1469. 
15. Thakar JI, Plants of Kutch and their utility (In Gujarati), Rajkot, 1926.

\section{Cite this article as:}

P. K. Patel, Vandana Vyas and A. V. Pandya. Muntingia calabura L. (Elaeocarpaceae): A New Generic Record to the Flora of Gujarat State, India. Annals of Plant Sciences 5.2 (2016): 1269-1271.

Source of support: Nil

Conflict of interest: None Declared 